\title{
Managerial remuneration and disciplining in the UK: A tale of two governance regimes
}

\author{
Luc Renneboog* \\ Tilburg University
}

\author{
Grzegorz Trojanowski** \\ University of Exeter
}

This version: 12 July 2011

\begin{abstract}
We simultaneously analyze two mechanisms of the managerial labor market (CEO turnover and remuneration schemes) in two different regulatory regimes, namely before and after the sweeping governance reforms adopted in the UK in the 1990s. We employ sample selection models to examine firms in a pre-Cadbury Code period (1988-1993) and a post-Combined Code period (1998-2004). CEOs’ compensation and CEO replacement are performance-sensitive in both periods. There is little evidence of outside shareholder monitoring, whereas powerful CEOs successfully resist replacement irrespective of corporate performance. With regard to CEO remuneration, we sketch a nuanced picture as we find some evidence supporting the alignment of interests hypothesis, but also supporting the managerial power or skimming model for managerial remuneration practices in the UK prior to the governance reforms. In particular, equity-owning CEOs compensate disappointing stock performance by augmenting their monetary compensation. Our results are consistent with the widely perceived failure of internal governance mechanism in tackling the agency problems associated with managerial pay: these mechanisms have relatively little impact on executive remuneration. We also conclude that the regulatory effort undertaken in the UK over the 1990s has had at best a moderate effect on increasing executives' accountability and performance sensitivity of their turnover.
\end{abstract}

JEL classification: G30; G32; G34; J33

Keywords: corporate governance; agency costs; CEO remuneration; CEO turnover; ownership and control; entrenchment

* Tilburg University, P.O.Box 90153, 5000 LE Tilburg, Netherlands. Tel.: +31 13 4668210; fax: +31 13 4662875; e-mail: Luc.Renneboog@UvT.nl.

** Corresponding author. Xfi Centre for Finance and Investment, University of Exeter Business School, Rennes Drive, Exeter EX4 4ST, UK. Tel.: +44 1392 723441; fax: +44 1392 722525; e-mail: G.Trojanowski@ex.ac.uk. 


\title{
Managerial remuneration and disciplining in the UK:
}

\section{A tale of two governance regimes}

\begin{abstract}
We simultaneously analyze two mechanisms of the managerial labor market (CEO turnover and remuneration schemes) in two different regulatory regimes, namely before and after the sweeping governance reforms adopted in the UK in the 1990s. We employ sample selection models to examine firms in a pre-Cadbury Code period (1988-1993) and a post-Combined Code period (1998-2004). CEOs' compensation and CEO replacement are performance-sensitive in both periods. There is little evidence of outside shareholder monitoring, whereas powerful CEOs successfully resist replacement irrespective of corporate performance. With regard to CEO remuneration, we sketch a nuanced picture as we find some evidence supporting the alignment of interests hypothesis, but also supporting the managerial power or skimming model for managerial remuneration practices in the UK prior to the governance reforms. In particular, equity-owning CEOs compensate disappointing stock performance by augmenting their monetary compensation. Our results are consistent with the widely perceived failure of internal governance mechanism in tackling the agency problems associated with managerial pay: these mechanisms have relatively little impact on executive remuneration. We also conclude that the regulatory effort undertaken in the UK over the 1990s has had at best a moderate effect on increasing executives' accountability and performance sensitivity of their turnover.
\end{abstract}

JEL classification: G30; G32; G34; J33

Keywords: corporate governance; agency costs; CEO remuneration; CEO turnover; ownership and control; entrenchment 


\section{Introduction}

Executive compensation remains one of the most widely discussed governance issues in the UK where it continues to attract the attention of the business community, academics, and the popular press. Numerous calls for improving the code of good practice for managerial remuneration contracting and for stronger shareholder involvement in the pay-setting process followed the dispute over the pay of the GlaxoSmithKline’s CEO Jean-Paul Garnier in 2003. This shareholder revolt against corporate 'fat cats' and the concerns of the investment community were voiced as follows:

Companies must be free to run themselves as they think best and to pay their executives appropriately. But they must also act responsibly when company performance is poor. Shareholders must hold them to that responsibility, and ensure that the days of the overfed felines are numbered (The Times, May 20, 2003).

However, governance problems pertaining to managerial compensation do not appear to be confined either to the UK or the first years of the $21^{\text {st }}$ century as the recent financial crisis put the issue into the spotlights again:

As you may have noticed, pay is back on the corporate governance agenda in a big way. As the regulatory response to the credit crisis on both sides of the Atlantic begins to take shape, it is looking increasingly likely that remuneration will be a key area of consideration for both investors and other interested parties. The current crisis is leading to a fairly fundamental reappraisal of financial markets and how key organisations within them operate, and remuneration surely cannot avoid an overhaul (The Financial Times, August 18, 2008).

Over the 1990s, the UK corporate governance regime experienced a series of sweeping governance reforms initiated by the Code of Best Practice (so-called Cadbury report) in 1992 (and incorporate in the listing rules of the LSE in July 1993) and then followed by Greenbury report in 1995, Hampel report in 1998, and, finally enshrined in the Combined Code of Corporate Governance in 1998 [51]. While some evidence exists on the effects of the earlier reforms, in particular of the Cadbury report (see e.g. [23] and [34]) for the effects of the Code introduction on CEO dismissal and executive compensation, respectively), this paper provides a comprehensive examination of managerial remuneration and disciplining in the UK in both the pre-reform period (i.e. before 1993) and in the post- 
reform period (i.e. as of 1998). It allows us to rigorously assess the efficiency of the governance changes and relate to the critics claiming that the recommendations of the British governance committees did not have sufficient clout to curb the excesses in managerial compensation (see e.g. [50] and the quotes above). One of the main deficiencies of widely-held public corporations - 'strong managers, weak owners', in the words of Roe [60] - may actually have led to a situation where the mechanisms meant to improve the governance standards like performance-related pay are misused by powerful directors to extract substantial rents from the companies they work for [9]:

One of the really alarming aspects of global capitalism during the 1990s was the increasing disconnect between the managerial cadres who ran companies and shareholders who owned them. Managers and the boards that appointed them stopped seeing themselves as custodians of other people's money and became a self-serving interest group, dedicated to grabbing more of the cake (The Independent, May 21, 2003).

The early agency literature stipulates that shareholders' interests can be protected because managerial incentives can be (re)structured. As such, managers attempt to avoid poor performance due to the threat of dismissal and are stimulated to reach strong corporate performance as a result of the rewarding and incentive effects of compensation contracts [40, 56]. However, more recent US empirical literature casts doubt on the hypothesis of alignment of interests which may be brought about by payfor-(stock price) performance contracts and performance-related dismissals. For instance, Bebchuk and Fried's [7] 'managerial power model' points out that executive compensation should be seen as a manifestation of agency problems rather than a solution if remuneration contracting is not embedded in a proper governance system. Likewise, Bertrand and Mullainathan [11, 12] give evidence that the performance-related contracts in the US do not correct for windfall profits which are not related to managerial efforts or skill, and that CEOs are hence paid for luck. Furthermore, they propose a model whereby 'agents without principals' (managers without proper governance mechanisms like a monitoring blockholder) are skimming corporate profits. Our results give a nuanced picture for the UK. We show evidence of contractual alignment, but we also detect circumstances which point at the danger of managerial self-dealing (in particular, in the pre-reform period). Self-dealing may particularly arise in firms where CEOs have a lot of discretion in decision making, which may result from a lack of 
monitoring by outside shareholders or the board of directors. Some of our results show indeed that powerful CEOs are shielded from forced departures and seem able to choose their preferred remuneration-related performance benchmark. This study thus contributes to recent literature on the alignment versus skimming hypotheses, and focuses on the UK.

Although a large body of academic literature exists (especially for the US) on both managerial disciplining and managerial compensation, these two aspects of the managerial labor market are usually -with the notable exception of Coughlan and Schmidt [21]- treated separately. However, the two governance mechanisms in question are likely to be intertwined such that the results of studies of executive turnover and of managerial remuneration in isolation are likely to be biased. Furthermore, each of these governance mechanisms only addresses the agency problems at specific ranges of corporate performance. For instance, performance-sensitive managerial compensation contracts are only designed for average or high levels of performance because management may not be induced to generate further efforts when they realize that the minimal performance thresholds triggering bonuses are out of reach. Likewise, Jensen and Murphy [42] argue that the probability of CEO dismissal is too low to align effectively the interests of managers and owners. Consequently, in order to cover a more complete spectrum of incentives, the carrot (performance-related compensation) and the stick (dismissal) need to be studied simultaneously. A simultaneous treatment of both governance mechanisms econometrically translates into a Heckman sample selection model (type-2 Tobit). This technique mitigates the sample selection biases induced by sample endogeneity affecting many of the studies analyzing managerial compensation. We document that our estimation technique yields unbiased results as opposed to fixed-effects panel data regressions. Our paper contributes to the literature by correcting the findings of earlier UK research which fell short of finding a relation between managerial remuneration and corporate performance (or documented a very weak relation). The lack of performance sensitivity in earlier UK studies may result from the biases induced by inappropriate estimation methodologies or may be due to benchmarking problems (we study a wide set of industryadjusted performance measures).

We analyze listed UK firms and find the CEO compensation to be performance-sensitive: remuneration rewards either past good accounting or stock price performance. Nevertheless, we cannot 
unambiguously show that remuneration contracts align the interests of managers and shareholders, nor can we demonstrate that the skimming/managerial power model is valid in all cases. The fact that the levels of CEO compensation are lower when executive directors are powerful (in terms of voting rights) supports the alignment of interest-hypothesis. However, for the pre-reform period, we find that when firms incur negative abnormal returns and their CEOs derive substantial wealth from the equity investment in their firms, CEOs compensate the disappointing stock performance by augmenting their monetary compensation. This suggests self-dealing and therefore provides some support for the skimming or managerial power theory. CEOs who also exert the function of chairman (and hence dominate the board) earn more when accounting performance is high (but not when share price performance has increased). Thus, powerful managers seem to prefer accounting standards as an evaluation criterion, presumably because they have more discretion over this benchmark and hence over their monetary compensation. In contrast, in firms with strong outsider (monitoring) shareholders, management cannot pick its preferred performance benchmark as it is required to focus on the creation of shareholder value. The aforementioned relation between CEO power and the intricacies of payperformance sensitivity persist in the post-reform years. In both periods analyzed, the CEOs of monitored firms (in particular of firms where non-executive directors and outside shareholders control large share blocks) enjoy lower remuneration, irrespectively of performance.

In the pre-reform period, there are few characteristics of the board structure (apart from the separation of CEO and chairman) which have an impact on the pay-for-performance sensitivity. The proportion of non-executive directors on the board does not seem to have an impact on the remuneration policy of the firm. Furthermore, the presence of a remuneration committee has no significant impact either. In this respect, our results appear consistent with the widely perceived failure of this mechanism in tackling governance problems. Interestingly, in the post-reform period, a larger proportion of non-executive directors on the board weakens the link between CEO compensation and accounting performance measure.

We also analyze the termination of a CEO employment contract. First, we find that CEO replacement rates are comparable in pre- and post-reform periods. Second, involuntary or forced turnover is performance-sensitive in both periods. Third, outside shareholders (institutions, families or 
individuals, other corporations) do not seem to be involved in general in disciplining the CEO even in the wake of poor performance (in either of the periods). In line with earlier research, we find that prior to the governance reforms of the 1990s, non-executive directors owning share blocks seem to protect the incumbent CEO in poorly performing companies, while in the post-reform period this effect is no longer significant (in line with the codes’ spirit of fostering non-executive directors' governance role). Fourth, CEOs also holding the positions of chairmen of the board successfully impede replacement irrespective of corporate performance in the pre-reform period. Finally, until 1993, large boards and boards with a high proportion of non-executive directors replace the CEO more frequently. However, these boards are not more apt to replace underperforming management in either the pre-reform or the post-reform period.

The remainder of the paper is organized as follows. In the next section, the research hypotheses are motivated. Section 3 discusses the sample selection procedure, describes the variables and reveals the data sources. In the same section, the different estimation techniques are explained. Section 4 presents the results, while Section 5 discusses detailed robustness tests. The conclusions are presented in Section 6.

\section{Determinants of CEO compensation and of managerial turnover}

\subsection{Background agency literature}

Coughlan and Schmidt [21] were the first to document that the likelihood of forced turnover is a decreasing function of corporate performance; a finding further corroborated by an extensive literature (a.o. [24] for the US, and [23] and [29] for the UK). ${ }^{1}$ The theoretical blueprint of pay-for-performance remuneration was laid by the principal-agent models of Jensen and Meckling [41], and Grossman and

\footnotetext{
${ }^{1}$ The disciplinary character of managerial turnover is influenced by board size [67], board composition [65], ownership structure [25], and is industry-dependent [59]. Forced executive resignations in the US are usually accompanied by positive and statistically significant abnormal stock performance, provided that an outsider is appointed as the CEO [61].
} 
Hart[36]. ${ }^{2}$ The performance-sensitivity of managerial compensation is empirically well documented for US firms (e.g. [42]): executive pay depends on both past stock returns and past accounting measures [63] as well as on relative measures of performance [31]. Still, the level of executive compensation depends not only on past performance; also important are company size [34, 55] and CEO age and tenure [19]. ${ }^{3}$ The optimal balance of stock-based and monetary compensation solves a trade-off between short- and long-term incentives [57].

The recent literature criticizes the agency approach that considers managerial compensation as the optimal outcome of the contracting problem [7, 11]. According to the 'skimming model' of the executive remuneration, directors are able to set their own (excessive) pay in firms with inferior governance standards [12]. Apart from the availability of funds, the only constraint deemed to curb such a managerial discretion is the fear of causing 'outrage' among shareholders potentially angered by excessive pay of the company’s executives [8].

\subsection{Motivation of hypotheses}

The impact of the various corporate mechanisms (internal devices such as board composition, pay-for-performance, and external mechanisms such as ownership concentration by type of shareholder) will vary over time and their effectiveness will depend on the regulatory framework. Over the past 15 years, several important regulations were introduced. The Combined Code of Corporate Governance was launched in 1998 and united 3 earlier corporate governance codes: (i) the Cadbury report on good governance which was introduced in December 1992 (and included in the listing rules of the London Stock Exchange in July 1993), (ii) the Greenbury report of 1995 on remuneration

\footnotetext{
${ }^{2}$ A multi-period setting has enabled the analysis of career concerns that also affect executive compensation contracts $[15,33]$.

${ }^{3}$ Furthermore, the following characteristics also explain managerial remuneration: ownership structure [20], board composition [37], the threat of a takeover [4], merger and acquisition policy [33], company risk, growth opportunities, dividend policy [49], the country where the company is operating [19], and the gender of the executive [48].
} 
transparency, and (iii) the Hampel report of 1998 which emphasized principles of good governance, rather than 'box-ticking' explicit rules [51].

The period prior to 1993, precedes the implementation of the first of the corporate governance reports adopted in the UK. ${ }^{4}$ This period is characterized by lower corporate governance standards than more recent years, and is therefore particularly interesting from an agency-theory point of view. Our second six-year sample period, labeled the post-form period, covers the years following the adoption of the Combined Code (1999-2004). Using two time periods enables us to better assess the efficiency of improved governance standards as recommended by the codes. In the remainder of this subsection, we formulate our main hypotheses on the governance effects on turnover and on remuneration. We also indicate in which time period - the pre-reform or post-reform period - we expect the hypotheses to hold (more strongly).

The importance of the disciplining role of managerial dismissals is widely accepted. Still, setting a correct performance yardstick is problematic as both accounting and stock price performance have some deficiencies. Accounting information records only past corporate performance and can be manipulated over a period of several years by top management (see e.g. [16]). Stock price performance captures the firm's ability to generate value in the future and may hence already include the effects of an expected change in CEO. Therefore, we argue that both stock- and accounting-based measures of performance provide incremental information about executives’ productivity.

Decisions about hiring and firing top management are ultimately taken by the board of directors. ${ }^{5}$ The higher the degree of independence of the board from top management, the higher the level of performance-induced turnover is likely to be. Still, the empirical US literature comes up with conflicting results. ${ }^{6}$ For the UK, Franks et al. [29] find that a high proportion of independent directors

\footnotetext{
${ }^{4}$ The Cadbury report was first published in December 1992; it is possible that some firms may have adopted some of the Cadbury recommendations in the final year of our first sample.

${ }^{5}$ Throughout the paper, we use the UK definition of a director. A UK board of directors consists of executive directors (frequently called officers in the US) and non-executive directors (called directors in the US).

${ }^{6}$ Weisbach [65] shows that board structure affects the likelihood of disciplinary turnover: poorly performing CEOs are more frequently fired provided that the board is outsider-dominated. This conclusion is challenged by
} 
does not lead to stronger managerial disciplining in poorly performing firms, while this conclusion is challenged by Dahya et al. [23]. According to Franks et al. [29] what does seem to matter is separating the functions of the CEO and the chairman of the board. Also, Yermack [67] reports that smaller boards operate more efficiently as they are more prone to replace underperforming CEOs of the US companies.

Hypothesis 1a (Governance effects on turnover): Board independence positively affects the likelihood of managerial turnover in poorly-performing firms. An inverse relation is expected for board size.

As there are hardly any requirements in corporate law on board structure in the pre-reform period, we expect a stronger impact of board structure on turnover in the post-reform period (following the arguments by Dahya et al. [23]). An alternative hypothesis is that in the post-reform period, the board structures (degree of independence, number of non-executive directors, separation of the positions of CEO and chairman etc.) do not vary to a large degree due to the implementation of the governance recommendations. Therefore the impact of board structure on turnover is marginal. If it were the case, superior internal board mechanisms (such as board independence which can be expected to stimulate good governance) may only make a difference in the pre-reform period.

The essence of the agency literature is that, in order to induce agents to exert (costly) effort, the principal has to provide them with appropriate incentives. Jensen and Meckling [41] suggest (partial) equity ownership by managers as a way of mitigating this problem, but Murphy [56] finds only little empirical support for this mechanism. Fama [28] discounts the idea of pay-for-performance contracts for managers with short track records because, if managers believe that subsequent wage offers will depend on current levels of performance, they will work hard today to build up reputational value independent of incentive compensation. Holmström [40] challenges this idea and shows that although

\footnotetext{
Mikkelson and Partch [54] and Agrawal and Knoeber [3] who show that managerial turnover is unrelated to board composition. Instead, turnover seems to result mainly from the pressure of the takeover market [52]. Importantly, more recent studies (e.g. [1], [62]) tend to suggest that executive turnover appears beneficial to shareholders, in particular, if the departing CEO is strongly entrenched.
} 
the effects of labor-market discipline can be substantial, it is not a perfect substitute for contracts. ${ }^{7}$ Gibbons and Murphy [32] extend the Holmström [40] model by introducing Fama's [28] reputation concept and show that the best compensation contract optimizes total incentives (the combination of the implicit incentives from career concerns and the explicit incentives from the compensation contract).

Managerial compensation schemes may be an appropriate device complementing performancerelated turnover for the following reasons. First, many managers can be subjected to this incentive mechanism, while performance-induced disciplinary turnover only affects a few top managers. Second, for industries where industry-specific skills are required, performance-based compensation is likely to be a more effective solution to agency problems than the threat of dismissal. Third, as disciplinary turnover penalizes underperformance, the mere fact of being able to avoid poor performance (and, hence dismissal) does not constitute the right incentive for well-performing managers to pursue a valuemaximizing strategy. If higher managerial effort induces better corporate performance, then there is an important rewarding role for performance-dependent bonus and option schemes. However, imperfect observability of top management's actions creates opportunities for moral hazard that adversely affect the contracting with a manager [39]. The efficiency of contracting can be improved by using informative signals about executives’ effort. Following this argument, Bushman and Indjejikan [15], and Kim and Suh [47] develop models in which the CEO's compensation depends on both accountingand stock-based performance measures. Both indicators are considered noisy signals of managerial effort, but as long as they are incrementally informative about managerial actions, they enter a performance-dependent wage formula with non-zero weight. ${ }^{8}$

Corporate governance standards influence the terms of CEO remuneration contracts [12]: the degree of independence of the board of directors may have a direct impact on managerial compensation as it is the non-executive directors (or their representatives in the remuneration committee) who set the remuneration contracts. In a firm whose board of directors is dominated by a powerful CEO (for

\footnotetext{
${ }^{7}$ In the absence of contracts, managers work too hard in their early years (when market is still assessing the manager's ability) and not hard enough in later years.

${ }^{8}$ This argument of using both types of performance measures (stock- and accounting-based) as determinants of CEO compensation is also invoked in some of the empirical literature for US firms [20, 45, 53].
} 
instance, when he or she also serves as the chairperson), the terms of the top management's remuneration contracts are more likely to be influenced by the CEO [9]. Yermack [67] also argues that smaller boards appear to act more frequently in the shareholders' interest than larger boards. In particular, he documents an inverse relationship between board size and the performance sensitivity of managerial compensation.

Hypothesis $1 b$ (Governance effects on compensation): Board independence positively affects performance sensitivity of the CEO's compensation. An inverse relation is expected for board size.

We expect the above hypothesis to be supported more strongly in the post-reform period as it may take a strong non-executive board/remuneration committee to impose an effective pay-forperformance mechanism. ${ }^{9}$

For the US, there is ample evidence that forced turnover follows from monitoring by large (activist) block holders and by the external market for corporate control (e.g. [13], [26]). For UK firms, Franks et al. [29] confirm that these mechanisms also play a leading role in the replacement of management. The intensity of monitoring may not only depend on mere ownership concentration, but also on the type of blockholders. In particular, substantial insider ownership may lead to managerial entrenchment, which decreases the performance-sensitivity of managerial turnover and reduces the likelihood of CEO dismissal [22]. In contrast, outside blockholders may hold management responsible for poor performance and attempt to remove them.

Hypothesis 2a (Blockholder identity effect on turnover): The type of controlling shareholders affects the likelihood of managerial turnover: monitoring by outside blockholders (institutions, families and individuals, industrial firms) leads to increased performance-related CEO removal, whereas insider blockholders impede top executive changes in underperforming firms.

We expect a stronger relation between the presence of share blocks and forced of top management for the post-reform period. The reason is that shareholders have become better informed as

\footnotetext{
${ }^{9}$ However, following the reforms, there may be less cross-firm variability in board independence such that it may be more difficult to discern the effect of board independence on pay-performance sensitivity.
} 
a consequence of the increased corporate transparency requested in the various codes constituting the Combined Code. Furthermore, shareholders have become more vocal and activist (at annual meetings and behind the scenes (see e.g. [10])

Shareholders monitor the firm when their share stakes are sufficiently large and the benefits from monitoring exceed the costs [46]. Such powerful shareholders may also set the terms of CEO employment contracts. Clay [17] argues that monitoring activities are delegated to some classes of owners and that the presence of activist shareholders leads to higher levels of CEO compensation and increasing performance-sensitivity. In contrast, in firms where managers control large equity stakes and/or where the ownership is diffuse, managers are likely to enjoy a high level of decision discretion such that they can promote compensation schemes with only a limited relation to share price performance. $^{10}$

Hypothesis $2 b$ (Blockholder identity effect on compensation): The presence of strong outside blockholders positively affects the performance sensitivity of the CEO's compensation, whereas the presence of large executive directors' holdings induces the opposite effect.

We expect that Hypothesis $2 \mathrm{~b}$ is more strongly supported in the post-reform period. The reason is that subsequent to 1995, firms ought to introduce pay-for-performance in their remuneration contracts and were expected to disclose the contract details of all the executive and non-executive directors. While stopping short of mandating shareholders' vote-on-pay at annual general meetings (AGMs), the Greenbury Report actively encourages shareholders to voice their concerns in the form of resolutions at the AGMs and recommends that executive long-term incentive schemes be approved by shareholders.

The discussion above leaves out one potentially important group of shareholders, namely nonexecutive directors. The relationship between the size of their equity stakes and CEO compensation or turnover is an open empirical issue. On the one hand, if non-executive directors assume their fiduciary duties appropriately and act in the interest of all shareholders, the impact of non-executives' voting power on CEO compensation and turnover will be similar to that of the outside blockholders (postulated

\footnotetext{
${ }^{10}$ Managers would then prefer remuneration packages related to accounting benchmarks as these can to some extent be manipulated by management [43].
} 
by Hypotheses 2a and 2b). On the other hand, if non-executive directors believe that their careers are closely tied to the fate of the incumbent CEO, they may opt to support the incumbent management and shield them from disciplinary actions. This would be in line with the findings of Franks et al. [29] who argue that non-executive directors frequently support the incumbent management even in the wake of poor performance. Thus, while testing for Hypotheses 2a and 2b, we control for the size of equity holdings controlled by non-executive directors, but a priori we do not hypothesize about the direction of the effect.

\section{Sample description and methodological approach}

\subsection{Sample description and data sources}

We analyze and compare the determinants of managerial compensation and turnover between two six-year periods: the pre-reform period (1988-1993) and the post-reform period (1999-2004). The pre-reform period precedes the implementation of the first of the corporate governance report adopted in the UK. ${ }^{11}$ The post-form period, covers the years following the adoption of the Combined Code in $1998 .^{12}$

The pre-reform period sample consists of 250 UK firms and is randomly drawn from the population of UK companies listed on the London Stock Exchange, excluding financial institutions, real estate companies and insurance companies. For a company to be included in the sample, we require that data are available for at least three consecutive years within the six years time window. Hence, the sample also includes those firms that were taken over or went bankrupt. Seven of the 250 companies were dropped because accounting data were not available from Datastream. All data on managerial compensation, turnover and board composition for the pre-reform sample were hand-collected and retrieved from the Directors' Report and the Notes in the annual reports. The same source is used to

\footnotetext{
${ }^{11}$ It is possible that some firms may have adopted some of the Cadbury recommendations in the final year of our first sample. Excluding year 1993 from our data does not materially influence the results presented in this paper.

${ }^{12}$ It should be noted that the Combined Code was amended in 2003 (when the Higgs report on a more active and independent role of non-executive directors was published) and in 2007 [30, 51]. We only study the impact of the main regulatory changes (which took place between 1993 and 1998.
} 
collect ownership data for each year of the period 1988-1993. All the directors' holdings greater than $0.1 \%$ are recorded as well as other shareholders' stakes of 5\% and more (3\% and above from 1990 when the statutory disclosure threshold was reduced). The status of the directors (executive/non-executive) and the dates of joining and leaving the board were also obtained from the annual reports and from contacting the firms directly by phone or fax. Non-beneficial share stakes held by the directors on behalf of their families or charitable trusts were added to the directors' beneficial holdings. Although directors do not obtain cash flow benefits from these non-beneficial stakes, they can usually exercise the voting rights. For equity stakes in Nominees accounts, the identity of the shareholders was found by contacting the listed firms directly. In $97 \%$ of these cases, the shareholders of Nominees accounts were institutional investors.

The post-reform sample is much more comprehensive and it is the intersection of the three databases: BoardEx (for managerial compensation, turnover, and board composition data), Worldscope (for accounting and other financial data) and the Price Waterhouse Coopers ownership database. This procedure yields a sample of 1,407 UK companies quoted on the London Stock Exchange (which corresponds to a sample of 6,424 CEO-years). The ownership database provides information on all the holdings of the company directors and all the holdings of 3\% or above for the other shareholders. The procedures for classifying non-beneficial stakes and Nominee accounts in the post-reform sample are the same as the ones outlined above for the pre-reform sample.

\subsection{Variable definitions and data description}

In our pre-reform sample, approximately $11 \%$ of CEOs lost their position in a given year (Table 1), while the number for the post-reform period is slightly lower at $9.9 \%$. This result is different from the one obtained by Dahya et al. [23] who document the increase in turnover rates following the implementation of the Cadbury code. The turnover data are corrected for natural turnover. ${ }^{13}$ As

\footnotetext{
${ }^{13}$ We distinguish between natural and forced turnover, classifying a resignation as 'natural' if the director was described as having left the board for reasons of retirement, death or illness. Otherwise the resignation was classified as being forced. The normal retirement age is between 62 and 65 but we took 62 as the minimum retirement age and viewed any earlier retirement as forced unless the databases employed provided details of the stipulated retirement age for a particular CEO (this information was only available for the post-reform sample).
} 
expected, CEO turnover most of turnover occurs in the lowest quintile of corporate performance. The median and mean logarithm of the monetary compensation (salary and bonus) in the pre-reform period was 11.88 and 11.91, respectively (which corresponds to $£ 144,000$ and $£ 149,000$ ). Expectedly, the corresponding numbers for the 1999-2004 sample are higher at 12.65 and 12.69, respectively (equivalent to $£ 312,000$ and £326,000). The improved disclosure requirements following the implementation of the Greenbury report (of 1995) enable us a more detailed analysis of the equitybased components of the compensation package. ${ }^{14}$ These components (stocks, options, and Long-Term Incentive Plans or LTIPs) constitute a substantial part of the total CEO compensation in the post reform period: the mean and median logarithms of total compensation are equal to 12.93 and 13.01 , respectively (which correspond to $£ 413,000$ and $£ 448,000$ ).

The median age of a CEO is 52 years (with a mean of 52.6) for the pre-reform sample. The numbers for the post-reform sample (51 and 50.5, respectively) are slightly lower. While in the 19881993 period the median tenure equaled 4 years (with a mean of 5.2), it was considerably shorted in the period 1999-2004 with a median (mean) tenure is merely 2.9 (4.9) years. In the pre-reform period, every third CEO also held the position of the chairman of the board of directors, but this proportion has decreases substantially following the corporate governance codes (as in the Combined Code) to about $15 \%$.

We observe a decrease in board size over time: while in the pre-reform period the median board consists of 9 directors, the corresponding board size in the post-reform period is 7. Finally, in approximately $26 \%$ of the sample firm-years from the pre-reform period, CEO compensation is

\footnotetext{
${ }^{14}$ For the pre-reform period, only rudimentary information about equity-based CEO remuneration is disclosed. The annual reports usually only mention that management options had been granted during the financial year and/or were outstanding without consistently revealing the number of options involved, the exercise price, and the number of options exercised in the preceding year. As a robustness check, we investigate whether the equitybased remuneration influences the cash-based pay-for-performance relation by expanding the main models for the pre-reform sample with proxies of equity-based compensation in the pre-reform sample. We include proxies for the size of the stock/option grants, for the value of the CEO's stock grants, and for the wealth effects of CEO's equity holdings (see Section 5.2 for detailed definitions and the results).
} 
determined by a remuneration committee. In our post-reform sample, virtually all firms have such a committee.

\section{[Insert Table 1 about here]}

As is typical for Anglo-American firms, the ownership concentration is relatively low (Table 1). Most CEOs do not hold very substantial share stakes, but the corresponding numbers increase in recent years: the average CEO in the pre-reform period owns 2.8\%, whereas the corresponding number for the post-reform period amounts to $4.5 \%$. In the pre-reform period, the median of the combined shareholdings of all executive directors (excluding the CEO) is $0.1 \%$, with an average of about $4.6 \%$. After 1999, the numbers increase to $1.3 \%$ and $6.0 \%$, respectively. The average combined stakes of the non-executives do not exceed $4 \%$ in either period. The most important class of blockholders is the financial institutions: they hold a (cumulative) median stake of $13.0 \%$ (with a mean of $16.6 \%$ ) over the 1988-1993 period. The importance of this class of blockholders increased further in post-reform period: their median (average) blockholding amounts then to 22.5\% (24.6\%). Finally, other outsiders individuals, families and industrial firms - control on average $8.2 \%$ of equity in the pre-reform period and $5.2 \%$ in the post-reform period.

In order to control for (potential) size effects, we introduce the logarithm of total assets (in $£$ thousands) at the end of a given year. For the median (mean) company in our pre-reform sample, this the total assets equal approximately $£ 85$ million ( $£ 78$ million). For the 1999-2004 sample, the corresponding number is $£ 142$ million (£166 million). The median and mean ratios of capital gearing (defined as long term-debt on total assets) equal $29.7 \%$ and $32.7 \%$, respectively, for the pre-reform sample, and $16.5 \%$ and $21.4 \%$, respectively for the post-reform sample. We measure risk by the annual volatility of stock returns: the median (mean) values in the pre-reform and post-reform periods amount to $34.4 \%$ (37.4\%) and 30.3\% (33.0\%), respectively. Finally, we employ annual abnormal stock returns ${ }^{15}$ as well as return on assets (ROA) to capture corporate stock performance.

\footnotetext{
${ }^{15}$ For pre-reform period, stock return data are collected from the London Share Price Database (LSPD). Both a Dimson [27] correction for non-synchronous trading and a Vasicek [64] Bayesian updating are applied. For the post-reform period, we employ the Worldscope data to compute abnormal returns.
} 


\subsection{Methodology}

We simultaneously explain managerial turnover and compensation within a sample selection model framework. The model, often referred to as a type-2 Tobit model, is specified as follows:

$$
\begin{aligned}
& \left\{\begin{array}{l}
\text { Turnover }_{i t}^{*}=\mathrm{X}_{1 i t}^{\prime} \beta_{2}+\varepsilon_{1 i t} \\
\text { Compensation }_{i t}^{*}=\mathrm{X}_{2 i t}^{\prime} \beta_{2}+\varepsilon_{2 i t}
\end{array}\right. \\
& C E O_{-} \text {stayed }_{i t}= \begin{cases}1 & \text { if } \text { Turnover }_{i t}^{*}>0 \\
0 & \text { if } \text { Turnover }_{i t}^{*} \leq 0\end{cases} \\
& \text { Observed_compensation }_{i t}= \begin{cases}\text { Compensation }_{i t}^{*} & \text { if } \text { Turnover }_{i t}^{*}>0 \\
\text { not observed } & \text { if } \text { Turnover }_{i t}^{*} \leq 0\end{cases}
\end{aligned}
$$

where $\left\{\varepsilon_{1 i t}, \varepsilon_{2 i t}\right\}$ are drawn from a bivariate normal distribution with mean 0 , variances $\sigma_{1}^{2}$ and $\sigma_{2}^{2}$, and covariance $\sigma_{12}$ [5]. ${ }^{16} \beta_{1}$ and $\beta_{2}$ are vectors of the model coefficients. In our models, $i$ corresponds to a firm and $t$ to a year. Turnover $_{i t}^{*}$ and Compensation $_{i t}^{*}$ are underlying latent variables that are not observable. However, the sign of the Turnover $_{i t}^{*}$ variable can be observed and coded as a binary variable CEO_stayed ${ }_{i t}$ : if a CEO lost his or her job (i.e., Turnover $_{i t}^{*} \leq 0$ ) it is coded as 0 , otherwise it is coded as 1 . Obviously, compensation is only observed for CEOs who were not dismissed (see Equation 3).

$\mathrm{X}_{1 i t}$ and $\mathrm{X}_{2 i t}$ are the sets of explanatory variables explaining CEO turnover and compensation, respectively. They include the measures of stock and accounting performance, board characteristics, ownership structure variables, and other control variables (e.g., leverage, firm risk, time,

\footnotetext{
${ }^{16}$ In a standard setting, error terms are assumed to be i.i.d. drawings from a bivariate normal distribution. We relax the assumption of independence of $\varepsilon$ s across $t$ and allow clustering of observations corresponding to a given firm, i.e. we assume error terms to be i.i.d. across firms, but not necessarily for different observations within the same firm. All the reported standard errors of estimates are adjusted for clustering. This procedure enhances robustness of our findings and allows us to take the panel data structure of our sample explicitly into account. To estimate the type-2 Tobit models, we employ a two-step procedure suggested by Heckman [38], which yields consistent parameter estimates.
} 
or industry dummies). The two sets of explanatory variables, i.e., $X_{1 i t}$ and $X_{2 i t}$, are not disjoint (they can differ, however).

Throughout the paper we call Equation 1a the selection equation, while Equation $1 \mathrm{~b}$ is the regression equation. The selection equation explains CEO turnover, i.e., $C E O{ }_{-}$stayed $_{i t}=1$ corresponds to those firm-years when the CEO keeps his or her position. The regression equation explains the compensation of these CEOs in the subsequent year. As the notion of compensation sensitivity to previous year performance is not meaningful for new CEOs, we restrict the remuneration analysis to CEOs with tenures of more than one year. Estimating the parameters of the regression Equation 1b on the basis of the non-turnover sample only, would not be a valid alternative to the proposed method because the OLS estimator of $\beta_{2}$ is biased when the selection of the regression sample is endogenous (i.e., $\sigma_{12} \neq 0$ ). Instead, our sample selection model deals with the endogeneity of selection, and therefore renders reliable parameter estimates for the regression equation [35].

Our hypotheses are tested within Tobit-2 models with interaction terms. We allow the explanatory variables to be time-varying, which results in multiple observations for each of the analyzed firms. In order to assure the robustness of the results, we account for a possible dependence between different observations corresponding to the same firm. We allow for clustering and implement the procedure which assumes the observations to be independent across firms, but does not require different observations on the same firm to be independent.

Finally, we also analyze corporate remuneration using a fixed-effects and random effects panel regression framework in order to compare these estimates with the results from the sample selection models. ${ }^{17}$ This allows us to draw some conclusions about whether or not the fixed-effects methodology or simple OLS regressions, frequently used in previous research, biases the results of earlier studies.

\footnotetext{
${ }^{17}$ Fixed-effects and random-effects panel regressions are often used to model executive compensation. In the fixed-effects approach, firm-specific effects (i.e. $\alpha_{i}^{\prime}$ s) are treated as model parameters and are hence estimated. The random-effect model treats $\alpha_{i}^{\prime}$ s as the result of a random draw from some distribution (e.g., the normal one). For a data panel like ours (relatively large number of firms drawn randomly from an even larger population of companies), the use of a random-effects model is recommended, as the number of parameters to be estimated is
} 


\section{Results}

\subsection{The impact of performance on managerial disciplining and remuneration}

In Table 2, we examine whether performance influences CEO turnover (the selection equations of Panel A) and industry-adjusted CEO remuneration (the regression equations of Panel B). The results of Panel A support the disciplinary role of managerial turnover because performance is negatively correlated to future turnover (Model 1A). ${ }^{18}$ In the pre-reform period, this effect is statistically significant for abnormal stock returns (but also for the industry-adjusted accounting-based performance measure reported in models presented in subsequent tables; see below). Unsurprisingly, managers generating strong corporate performance are more likely to keep their positions during the subsequent year. A more detailed analysis of the parameter estimates highlights the economic significance: for instance, Model 1A implies that in the pre-reform period the probability that a CEO of a wellperforming company loses his or her job is almost half of the corresponding probability for the median performing company. In contrast, CEOs of poorly performing firms are almost twice as likely to lose their jobs than their counterparts of the median performing firm. ${ }^{19}$ In the post-reform period (Models $1 \mathrm{~B}$ and 1C), we find a stronger correlation with our accounting-based performance measure (return on assets), whereas the relation between turnover and stock performance is no longer statistically

substantially lower with this technique. Furthermore, more efficient estimates are obtained than with fixed-effects models. Still, the consistency criterion of such a random-effects approach requires $\alpha_{i}^{\prime}$ s to be uncorrelated with explanatory variables of the model, i.e. the $X$ 's [6]. Since the Hausman specification tests points out that in almost all our specifications this assumption is violated, we report the results from the fixed-effects approach.

${ }^{18}$ The performance coefficients in the regression equations are positive but this signifies that the relation between turnover and performance is negative because the dependent variable equals 1 if the CEO keeps his position and 0 when he departs (for reasons other than retirement).

19 The median firm is characterized by median values of firm-specific characteristics (performance, board composition, control variables). We define a well-performing company as a company where both performance indicators are at the top quartile of performance while control variables take median values. Finally, in a poorly performing firm both performance indicators are at the bottom quartile performance while control variables again take median values. 
significant. Consequently, in the post-reform period, the probability of a CEO losing his or her job (as implied by Model 1C) are equal to $8.3 \%, 7.2 \%$, and $9.5 \%$ in a median, a well-performing, and a poorlyperforming company, respectively. These findings do not unequivocally show that the performance sensitivity of CEO turnover increased following the implementation of the Cadbury code (which is the conclusion of [23]).

The regression equations in Panel B of Table 2 show a positive relation between, respectively, the monetary remuneration (fixed salary and bonus) and total remuneration (which also includes equitybased compensation such as option plans and LTIPs), and abnormal returns and accounting performance (Models 1A-C). We do find that both for the pre- and post-reform periods, the relation between CEO remuneration and the accounting and stock price performance measure is positive and statistically significant. As frequently documented in previous research, remuneration is strongly dependent on firm size both in the pre- and post-reform period (see e.g. [34]). We also show that risky firms also reward higher salaries to their top management.

\section{[Insert Table 2 here]}

We now perform a more detailed analysis and expand the above remuneration and turnover models with internal corporate governance characteristics (Section 4.2) and external governance devices (see Section 4.3), while controlling for firm size, risk, leverage and industry.

\subsection{Sample selection model results for CEO turnover}

\subsubsection{Internal governance}

Panel A of Table 3 shows that board structure has an important impact on CEO turnover in the pre-reform period (Model 2A). We find that: (i) The presence of larger boards facilitates the replacement of the CEO. It may indeed be that larger boards represent a larger internal pool of managerial talent. (ii) Boards with a larger percentage of outside, independent directors replace CEOs more frequently. (iii) When a person fulfills the tasks of CEO and chairman of the board simultaneously (which is still the case in one third of the firms in the pre-reform period), the likelihood of his or her replacement significantly decreases. This implies that more powerful CEOs can successfully impede their replacement. This danger of conflicts of interest provides further support for the need to separate 
the positions of CEO and chairman (as stipulated in the Cadbury report). One would expect all of the above characteristics of the internal corporate governance mechanism to be much stronger related to turnover in the wake of poor corporate performance. We find however that this is not the case: The interaction terms of the proportion of non-executive directors and either of the performance measures are not statistically significant in the pre-reform period. Also, the degree of entrenchment (the positions of CEO and chairman are combined) does not affect the performance sensitivity of turnover, as the corresponding interaction terms are insignificant.

\section{[Insert Table 3 here]}

In the post-reform period, we find no correlation between any of the board characteristics (and their interactions with performance) to the likelihood of forced managerial turnover with the exception of CEO-chairman duality (see below). This suggests that boards with a high proportion of nonexecutive directors do not appear significantly more apt to replace underperforming management. Hence, our results do not confirm Weisbach's [65] findings that outsider-dominated boards, supposedly more independent from management, are more able to enforce disciplinary turnover. Our findings indicate that the main prescription of the 'Recommendations for Good Corporate Governance' (the 1992 Cadbury report and its successors), i.e. strengthening the role of non-executive directors, may not be as effective as it is assumed.

Interestingly, the effect of CEO-Chairman duality gets reversed in the post-reform period: CEOs who are also chairmen are more likely to lose the CEO position. As the governance codes recommend the separation of the two positions, it may be the case that in the post-reform period, the cases where CEOs also act as chairmen reflect temporary solutions to the succession planning (e.g. CEO holds on to both jobs until a suitable replacement can be found for one the positions (frequently that of the CEO whereby the person in question subsequently only retains the position of non-executive chairman). As before, the interactions of the CEO-chairman duality variables with performance do not significantly affect the likelihood of CEO turnover. Thus, we conclude that our analysis fails to support Hypothesis 1a.

\subsubsection{External governance}


For the pre-reform period, Model 2A does not yield much support for Hypothesis 2a. Ownership concentration does not seem to affect the performance sensitivity of CEO turnover. In particular, neither an analysis with outsider ownership concentration (Model 2A), nor a more detailed analysis (not shown) with ownership concentration held by institutions (banks, pensions funds, mutual and investment funds, insurance companies), families and individuals not related to a director, other corporations, and the government give evidence of outside shareholder monitoring. In some models which do not include the internal governance mechanisms, strong insider control implies a higher probability that the CEO will not be removed. Executive directors with large ownership stakes appear able to successfully ward off any attempts to replace the CEO regardless of corporate performance. As these results are not robust in larger models, they are not reported. Model 2A of Table 3 shows that the size of the shareholdings controlled by non-executive directors does not have a direct impact on the likelihood of CEO turnover. Interestingly, however, the significance of the interaction term between the non-executives' stake and past stock performance indicates that non-executive directors tend to protect the CEOs of firms whose stock underperformed (which is in line with the findings by Franks et al. [29]). This result further illustrates the lack of monitoring by non-executive directors. Thus, poor performance may not only be the result of poor management, but maybe also of poor external corporate governance.

The situation for the post-reform period is similar: contrary to what Hypothesis 2a postulates, there is no strong link between ownership structures and the likelihood of managerial turnover in the post-reform period. Virtually all the coefficients corresponding to ownership variables or their interactions in selection equations of Models 2B, and 2C are not statistically significant.

Finally, our control variables reveal that, over the pre-reform period, CEOs of larger firms were more able to maintain their position, whereas in the post-reform period, CEOs seem to be more easily disciplined in larger firms. Capital gearing does not affect the likelihood of CEO turnover, while CEOs of risky firms are less likely to lose their jobs in post-reform period.

\subsection{Sample selection model results for CEO compensation}

\subsubsection{Internal governance}


We study the relation between top management remuneration, and performance and governance variables in both periods in Panel B of Table 3 (Models 2A-C). The impact of board size is consistently significant: CEOs of firms with large boards receive a larger compensation in both the pre-reform and post-reform periods. This effect is not performance-dependent in the pre-reform sample, while in the more recent period, the presence of larger boards strengthens the link between compensation and stock performance. Stronger abnormal returns are followed by higher monetary and total compensation (which distinguishes our results from those obtained for the US by [67]).

In the pre-reform period (Model 2A), a high proportion of non-executive directors, the presence of a remuneration committee, the separation of the functions of the CEO and the chairman do not seem related to the way managerial remuneration contracts are drawn up. The only statistically significant effect in this part of the analysis is the interaction of the CEO-Chairman indicator with accounting performance. Apparently, in the pre-reform period, the remuneration of those CEOs who also act as chairmen of the board, is more sensitive to the return on assets. A possible interpretation may be that powerful executives are able to have accounting performance adopted as the performance yardstick on which their remuneration will be partially based. Due to the large degree of discretion that powerful CEOs can enjoy, they could have been able to manipulate this benchmark in the pre-reform period by means of specific accounting choices for a number of years. Finally, the presence of a remuneration committee (consisting of non-executive directors) does not have a significant impact on CEO compensation in the pre-reform period.

In the post-reform period, Models 2B and 2C (see Panel B) demonstrate that CEOs who are members of boards with a larger proportion of non-executive directors enjoy higher levels of both monetary and total compensation. Board independence hardly matters for the performance sensitivity of CEO remuneration in the post-reform period. The only exception is the statistically significant coefficient for the corresponding to one of the interaction terms in Model 2B: it suggests that the presence of a substantial number of non-executive directors on the board weakens the link between monetary compensation and accounting performance. While the focus of the governance reforms implemented in the UK in the 1990s was amongst others to strengthen the role of non-executive directors, our results do not confirm any notable improvement in the governance efficiency of this 
mechanism. CEO-Chairman duality does not appear to affect either the level of managerial pay or its performance-sensitivity in the post-reform period. ${ }^{20}$ Overall, we find little relation between board structure and compensation in either of the periods analyzed and therefore, we reject Hypothesis $1 \mathrm{~b}$.

\subsubsection{External governance}

We show for both the pre-reform and post-reform periods that, when executive directors hold large share stakes, the CEO’s monetary remuneration is lower (Panel B of Table 3). It may be that when executive directors derive substantial wealth from their equity investments in their corporation, they care less about their monetary income. Still, for the pre-reform period, we find that when stock prices decrease, CEOs seem to compensate disappointing stock returns by augmenting their monetary compensation. Thus, Model 2A illustrates a pernicious remuneration incentive scheme by which CEOs receive a higher monetary compensation in the wake of poor stock performance of firms in which they can exert considerable voting power. Notably, this effect has disappeared in the post-reform sample. Still, given that the levels of compensation are lower in firms with powerful executive directors, we cannot fully support the managerial power (or the skimming) model for executive compensation as formulated by Bebchuk and Fried [7].

When outside shareholders hold share blocks, CEO compensation appears to be lower (see Models 2A-C). However, outside shareholders do not seem to impose an effective pay-for-performance remuneration scheme, as the interaction of the size of the outside blockholdings with corporate performance is not statistically significant. ${ }^{21}$ It may well be that pay-for-performance schemes and

\footnotetext{
${ }^{20}$ Only Model 2B suggests that CEOs who are also chairmen enjoy higher levels of cash-based compensation, but this effect is only marginally significant. We do not analyze the impact of the presence of a remuneration committee on compensation in the post-reform period. Following the recommendations of the governance codes, virtually all the firms have established such a committee by 1999 (i.e. the year when the post-reform sample starts).

${ }^{21}$ An analysis of the different types of outside blockholders does not give any significant results, apart from the fact that CEOs' compensation is less sensitive to the accounting-based benchmark in firms with a high proportion of equity controlled by financial institutions.
} 
shareholder control are supplementary monitoring mechanisms. Consequently, we only find partial evidence supporting Hypothesis 2b: there is no evidence that CEO remuneration is more performancerelated in outsider-dominated firms, but strong director control concentration leads to a lower performance sensitivity of CEO remuneration in the pre-reform years.

Finally, the size of the equity stakes controlled by non-executive directors is negatively related to the level of monetary CEO pay for both the pre-reform and post-reform periods (see Models 2A and 2B, Panel B of Table 3). Apparently, in companies where non-executive directors are less powerful (in terms of voting power), the CEO is more likely to enjoy higher levels of compensation. Still, powerful non-executive directors do not impose a performance-related remuneration scheme on the management as the interaction terms are not statistically significant.

Table 3 (Panel B) also provides some interesting insights concerning the impact of firm-specific control variables (size, gearing and risk) on CEO remuneration. In line with the UK remuneration literature (see e.g. [34]), CEOs of larger firms enjoy significantly higher industry-adjusted monetary compensation and higher total compensation. Top management usually tries to justify - rightly so or not - size-related compensation by the fact that special managerial skills (which are in short supply) are needed to manage larger firms. We also document that firm leverage has no impact on compensation in the pre-reform period. In more recent years, highly levered firms tend to pay their CEOs less.

Our results show that CEO remuneration increases with corporate risk. Aggarwal and Samwick [2], and Jin [44] argue that in an agency framework, managerial risk aversion implies that firm risk moderates the performance sensitivity of executive compensation. We verified this claim and expanded our models with interaction terms of company risk and performance (tables are available upon request). As none of these interaction terms are statistically significant, we fail to corroborate the risk hypotheses of the above studies.

\subsection{Sample selection model vs. fixed-effect panel regression}

Panels $\mathrm{C}$ of Tables 2 and 3 report the estimates of the correlation coefficients of the error terms in the selection and regression equations. The fact that those estimates are highly significant in most specifications confirms that an analysis of compensation performance-sensitivity based on a simple regression framework (OLS or fixed-effects estimations on a censored sample) is likely to suffer from a 
severe selection bias (see Section 3.3 above). In particular, ignoring the selectivity resulting from disciplinary CEO turnover can substantially bias the estimated strength of the remuneration rewarding effect (and of the impact of other covariates). Tables 4 and 5 illustrate this point: they report the estimates of panel data fixed-effect models explaining industry-adjusted CEO monetary and total compensation for the sample of CEOs who are at least one year in place (so, we also exclude CEOs who are newly appointed as was also done in the sample selection model discussed above). Models 3AC of Table 4 and Models 4A-C of Table 5 correspond respectively to Models 1A-C of Table 2 and Models 2A-C of Table 3.

Table 2 indicates that, as a consequence of ignoring the problem of sample selection, the statistical inference may lead to spurious conclusions. Based on the evidence of Table 4, we would reject the hypothesis predicting a significant relationship between past accounting performance and CEO compensation in all of the Models 3A-C. The significance of stock performance sensitivity of remuneration survives in some models, but the coefficient estimates are much lower than those reported in Table 2 which indicates that these fixed-effects results underestimate the true economic significance of the relations. The discrepancies between the parameter estimates obtained by these two estimation methods are even more outspoken for some other regressors (e.g. for the firm size variable), as can be observed in Table 5. These findings may explain the differences in conclusions between our analysis (based on a sample selection model) and earlier UK compensation studies based on simple OLS or fixed effects (e.g. [18]). This also suggests caution in interpreting the evidence on remuneration of past studies.

[Insert Tables 4 and 5 about here]

\section{Additional analyses and robustness tests}

\subsection{The effects of top management classification}

Whereas in the majority of UK firms, the identity of the CEO is undisputable, on other cases it is sometimes difficult to find out who is the (acting) CEO. If none of the executive directors carries the title of CEO, but there is a managing director, we consider the latter as CEO. If none of the board members hold a title of CEO or managing director while the board has an executive chairman, we 
consider this person as the CEO. As a robustness check for the post-reform period, we have also implemented an alternative approach (in line with that adopted by some earlier UK compensation studies, e.g. [34]) and have constructed a database where the highest paid executive director in a given firm year is labeled a CEO. Not surprisingly as the overlap between the two databases (employing different classifications) exceeds 93\%, this alternative approach yields the results (available upon request) virtually identical to those reported in the text.

\subsection{The effects of equity-based CEO remuneration in the pre-reform period.}

For the pre-reform period, we have only shown the results for the cash component of CEO remuneration. Reliable data on the other elements of executive compensation (equity-based compensation, mainly LTIPs and option grants) are scarce as prior to the Greenbury report, most firms only reported the base salary and bonus of the CEO. We also employed all available data to verify whether the presence of equity-based components of CEO's remuneration affect the conclusions drawn in Section 4.

We first construct proxies to capture the importance of option/stock grants awarded to the CEO. A first proxy for the size of such grants was calculated as the difference between the CEO's equity holdings in years $t$ and $t-1$, if the difference was positive and zero otherwise. This variable is positive for only about $9 \%$ of the CEO-years in the sample. ${ }^{22}$ For this subsample, the median (average) size of the grant was $0.5 \%(2.7 \%$, respectively) of the equity outstanding. Second, we construct a proxy to measure the value of CEO's stock grants. It was obtained by multiplying the size of the grant (defined above) by the market capitalization of the relevant firm. In the subsample of CEO-years where the proxy for the stock grant size is non-negative, the median (average) value of such a grant is about $£ 283,000$ (£11.73m, respectively). Third, we calculate the wealth effects of CEOs’ equity holdings in

\footnotetext{
${ }^{22}$ It may be the case that CEOs who are awarded stock grants sell their shares immediately following the grant [58]. If it is the case, our proxy underestimates the importance of such option grants. Another important source of noise is that this proxy does not only capture the stock awarded to the CEO resulting from a stock grant, but also the shares acquired by the CEO and financed from his or her personal wealth as well as the stock obtained as a result of the exercise of stock options. Consequently, the proxy may overestimate the size of the stock grants awarded to the CEO in a given year as well.
} 
order to obtain a direct measure of incentives resulting from managerial stock ownership. ${ }^{23}$ Such variables allow us to control for the possibility of ex post settling up in the bargaining between a CEO and the body responsible for remuneration-setting. More specifically, the board of directors (or the remuneration committee) who stipulate the terms of the CEO compensation may take into account the capital gains or losses experienced by the CEO over the previous year and adjust the monetary element of the remuneration package accordingly. Finally, we construct a dummy variable that equals one for the firm-years in which the CEO was granted stock options and zero otherwise. ${ }^{24}$ On average $73 \%$ of the firms reported that their CEOs received a stock option package.

In order to verify robustness of conclusions drawn in Section 4, we extend Models 1A and 2A using the four proxy variables discussed above. ${ }^{25}$ This allows us to examine the determinants of the CEO's monetary compensation, while controlling for non-cash components of the remuneration package. ${ }^{26}$ Not surprisingly, the size of the stock grant (i.e. the percentage of equity awarded to CEO) is negatively related to the level of a CEO's monetary compensation, but the corresponding coefficient is statistically insignificant. The results are stronger for the value of new stock grants: the corresponding coefficient is significantly negative in some models. The negative relationship is intuitive: nonmonetary elements of a CEO compensation package appear (imperfect) substitutes for monetary remuneration. Importantly, the extended models (including the proxies for the new stock grants) still support all the conclusions drawn from Models 1A and 2A.

\footnotetext{
${ }^{23}$ Two versions of the wealth effect variable were computed. The 'raw wealth effect' is obtained by multiplying the value of the CEO's equity stake by the raw stock return over the last year. For 'abnormal wealth effect', we multiply the value of the CEO's equity stake by the abnormal stock return over the last year.

${ }^{24}$ Information on neither the size of those grants nor about the terms of the options granted (e.g. exercise price, vesting period) was available. Moreover, our proxy may underestimate the importance of the grants, since the disclosure of such awards was not mandatory in the analyzed period.

${ }^{25}$ The corresponding estimation results are not tabulated in the text and are available upon request.

${ }^{26}$ This approach is similar to the one applied by Yermack [66]. His regressions explaining executives’ perquisite consumptions control for other forms of compensation.
} 
We find no relationship between the wealth effects of CEO equity holdings and the level of monetary compensation enjoyed by a particular CEO. The models employing proxies for wealth effects of CEO equity holdings still corroborate earlier findings. Finally, awarding a CEO with an option grant does not affect the level of CEO monetary compensation. Therefore, we conclude that the models extended with information on the equity-based remuneration corroborate our earlier conclusions.

\subsection{Alternative variable specifications in the simultaneous equations estimation.}

\subsubsection{Corporate performance}

We substitute unadjusted ROA and (yearly) changes in EBIT for our accounting performance measure and obtain similar results both in the regression and the selection equation. Alternative measures of stock performance (dividend changes as a signal of future value and Tobin's Q) correlate positively with remuneration in the regression equations, but do not seem to be used as a benchmark to remove the CEO. Finally, we extend the models by including two-year lags of the performance indicators. In most of the specifications, both the accounting- and market-based proxies lagged two years are insignificant, which implies that only recent performance information is used in the decision to dismiss or remunerate.

\subsubsection{Leverage}

The results are also robust to the choice of leverage proxy (book or market value), as none of the conclusions is challenged in these alternative specifications. Extending the models by firm-specific control variables capturing the changes in capital structure (such as a dummy variable for firms issuing new equity) does not materially affect the results.

\subsubsection{Model extensions by CEO age}

Several studies argue that CEO age is one of the crucial determinants of compensation and of turnover. We expand the models in Tables 2 and 3 by including CEO age and find that this variable has no impact on CEO compensation in either the pre-reform or the post-reform period (the corresponding coefficients are usually positive, though statistically insignificant). While for the pre-reform period we 
also find that older CEOs are less likely to suffer from forced replacement ${ }^{27}$, this result does not hold in the post-reform period as the relation between the CEO age and turnover is then insignificant. None of the other results presented in Tables 2 and 3 are challenged by the inclusion of age variable.

\section{Conclusion and discussion}

We simultaneously analyze two mechanisms of the managerial labor market: CEO turnover and remuneration schemes. Sample selection models are applied to firms listed on the London Stock Exchange over two periods of six years: 1988-1993 representing the period prior to the main changes in corporate governance regulation (the Cadbury, Greenbury, and Hampel reports which were bundled in the Combined Code) and the post-reform period of 1999-2004. Our approach yields some novel results compared to earlier UK research: the managerial remuneration and the termination of labor contracts play an important role in mitigating agency problems between managers and shareholders. We find that both the CEO’s industry-adjusted compensation and CEO replacement are performance-sensitive. Top executive turnover is shown to serve as a disciplinary mechanism in case of corporate underperformance, whereas the level of CEO compensation rewards good past performance although the performance criterion chosen depends to some extent on the ownership concentration and board structure. Especially our results on remuneration go against most past UK findings which had unveiled little pay-for-performance sensitivity, possibly due to biases introduced by inappropriate estimation techniques and an incorrect choice of remuneration measures and performance benchmarks.

Our analysis of CEO compensation reveals that CEOs are rewarded for corporate size and risk, but also for good accounting and stock price performance. The fact that the levels of remuneration are lower when executive directors are more powerful (in terms of voting rights) supports the alignment of interest-hypothesis which states that managerial ownership aligns the objectives of management and of other shareholders. However, for the pre-reform period we also find that, when CEOs derive substantial wealth from the equity investment in their firms and when stock prices decrease and negative abnormal

\footnotetext{
${ }^{27}$ The reason why we do not present these additional results in Tables 2 and 3 is that the CEO age variable is not disclosed for about one third of our sample firms for the pre-reform period.
} 
returns are incurred, these CEOs seem to compensate the disappointing stock performance by augmenting their monetary compensation package (salary and bonus). This suggests self-dealing and hence provides some support for an alternative theory, namely the skimming or managerial power hypothesis $[7,11]$. In the pre-reform period, CEOs who also exert the function of chairman of the board had more discretion over this benchmark and hence over their monetary compensation. In contrast, in firms with strong outsider (monitoring) shareholders, the management cannot pick its preferred performance benchmark as they are required to focus on the creation of shareholder value. The aforementioned problems of self-dealing in firms with powerful executives do not persist in the postreform years, which implies some improvement in corporate governance standards in the more recent regulatory regime.

In both periods, the CEOs of monitored firms (in particular in firms where non-executive directors and outside shareholders control large share blocks) enjoy lower remuneration, irrespective of performance. Moreover, in the pre-reform period, there are few characteristics of the board structure (apart from the separation of CEO and chairman) which have an impact on the pay-for-performance sensitivity. Neither the proportion of non-executive directors on the board nor the presence of a remuneration committee seem to have any impact on the remuneration policy of the firm. Interestingly, in the post-reform period, a larger board size is associated with a higher sensitivity of remuneration to stock performance, whereas a larger proportion of non-executive directors on the board weakens the link between CEO compensation and accounting performance measure. Overall, our results in this respect appear consistent with the widely perceived failure of internal governance mechanism in tackling the agency problems associated with managerial pay:

Ten years ago company boards set up remuneration committees to restrain greedy chief executives and make the salary setting process more transparent. Yet the excesses seem to have increased as a result. The committees create a veneer of respectability that protects chief executives from direct accountability. They rely on salary surveys and often use absurd overseas comparisons to justify huge salaries for UK-based executives. The committees generally want their chief executives to be paid an above-average wage, thereby creating an inflationary spiral... [B]ecause many chief 
executives sit on each other's remuneration committees, there is a suspicion of mutual backscratching (The Financial Times, May 20, 2003).

The implementation of the governance codes' guidelines has not resulted in increased CEO turnover rates: the dismissal probabilities appear comparable in the pre- and post-reform periods. We also document CEO dismissal to be performance-sensitive in both pre- and post-reform periods. There is little evidence of disciplinary monitoring by powerful outsider shareholders: institutions, families, or individuals, other corporations do not seem to be more apt to remove CEOs even in the wake of poor performance in either period. This finding is consistent with the sentiment recently expressed in the press:

The sad fact is that although reforms over the last few years have improved the transparency and accountability of firms to their shareholders, there hasn't been a corresponding increase in incentives or requirements for investors to act on the information provided. Asking questions about risks and long-term prospects of the companies they invested in makes good business sense for pension funds, insurers and savers. Some major investors and fund managers are taking on this challenge, but it is only through being consistently challenged and questioned by pension fund trustees that kind of responsible ownership will become the norm (The Financial Times, February 23, 2009).

In line with earlier research, we find that in the pre-reform period non-executive directors owning share blocks seem to protect the incumbent CEO in poorly performing companies, while in the post-reform period this effect is no longer significant (suggesting some improvement in governance standards following the implementation of codes' guidelines). In the pre-reform period, the lack of CEO-chairman duality in many firms fostered managerial entrenchment: prior to 1993 CEOs also holding the positions of chairmen of the board successfully impeded their replacement regardless of corporate performance. This confirms that the intention of the codes' governance guidelines to eliminate such types of entrenchment was entirely justified. Unfortunately, not all the codes' recommendations have yielded such beneficial effects. For instance, while prior to 1993 boards with a high proportion of non-executive directors replaced CEOs more frequently, this aspect of board independence does not appear to have had any effect on CEO dismissal in the post-reform period. 
Hence, we conclude all the regulatory effort undertaken in the UK over the 1990s has had at best moderate effect on increasing executives' accountability and performance sensitivity of their forced turnover.

\section{References}

[1] C.A. Adams, S.A. Mansi, CEO turnover and bondholder wealth, Journal of Banking and Finance 33 (2009) 522-533.

[2] R.K. Aggarwal, A.A. Samwick, The other side of the trade-off: The impact of risk on executive compensation, Journal of Political Economy 107 (1999) 65-105.

[3] A. Agrawal, C.R. Knoeber, Firm performance and mechanisms to control agency problems between managers and shareholders, Journal of Financial and Quantitative Analysis 31 (1996) 377-397.

[4] A. Agrawal, C.R. Knoeber, Managerial compensation and the threat of takeover, Journal of Financial Economics 47 (1998) 219-239.

[5] T. Amemiya, Tobit models: A survey, Journal of Econometrics 24 (1984) 3-63.

[6] B.H. Baltagi, Econometric Analysis of Panel Data, Wiley, Chichester, 2001.

[7] L.A. Bebchuk, J.M. Fried, Executive compensation as an agency problem, Journal of Economic Perspectives 17 (2003) 71-92.

[8] L.A. Bebchuk, J.M. Fried, D.I. Walker, Managerial power and rent extraction in the design of executive compensation, University of Chicago Law Review 69 (2002) 751-846.

[9] L.A. Bebchuk, J.M. Fried, Pay without Performance: The Unfulfilled Promise of Executive Compensation, Harvard University Press, Cambridge, 2004.

[10] M. Becht, J. Franks, C. Mayer, S. Rossi, Returns to shareholder activism: Evidence from a clinical study of the Hermes U.K. Focus Fund, Review of Financial Studies 22 (2009) 3093-3129.

[11]M. Bertrand, S. Mullainathan, Agents with and without principals, American Economic Review 90 (2000) 203-208.

[12] M. Bertrand, S. Mullainathan, Are CEOs rewarded for luck? The ones without principals are, Quarterly Journal of Economics 116 (2001) 901-932.

[13] J.E. Bethel, J.P. Liebeskind, T. Opler, Block share purchases and corporate performance, Journal of Finance 53 (1998) 605-634.

[14] J. A. Brickley, J.S. Link, J.L. Coles, What happens to CEOs after they retire? New evidence on career concerns, horizon problems, and CEO incentives, Journal of Financial. Economics 52 (1999) 341-377. 
[15] R.M. Bushman, R.J. Indjejikian, Accounting income, stock price, and managerial compensation, Journal of Accounting and Economics 16 (1993) 3-23.

[16]K. Chan, N. Jegadeesh, T. Sougiannis, The accrual effect on future earnings, Review of Quantitative Finance and Accounting 22 (2004) 97-129.

[17]D. Clay, The effects of institutional investment on CEO compensation, Working paper, University of Chicago, Chicago, 2000.

[18] M.J. Conyon, P. Gregg, S. Machin, Taking care of business: Executive compensation in the United Kingdom, Economic Journal 105 (1995) 704-714.

[19] M.J. Conyon, K.J. Murphy, The prince and the pauper? CEO pay in the United States and the United Kingdom, Economic Journal 110 (2000) 640-671.

[20] J.E. Core, R.W. Holthausen, D.F. Larcker, Corporate governance, chief executive officer compensation and firm performance, Journal of Financial Economics 51 (1999) 371-406.

[21] A.T. Coughlan, R.M. Schmidt, Executive compensation, management turnover, and firm performance: An empirical investigation, Journal of Accounting and Economics 7 (1985) 43-66.

[22]R. Crespi, C. Gispert, L. Renneboog, Cash-based executive compensation in Spain and UK, in: J. McCahery, P. Moerland, T. Raaijmakers, L. Renneboog (Eds), Corporate Governance Regimes: Convergence and Diversity, Oxford University Press, Oxford, 2002.

[23] J. Dahya, J.J. McConnell, N.G. Travlos, The Cadbury committee, corporate performance, and top management turnover, Journal of Finance 57 (2002) 461-484.

[24] D.J. Denis, D.K. Denis, Performance changes following top management dismissals, Journal of Finance 50 (1995) 1029-1057.

[25] D.J. Denis, D.K. Denis, A. Sarin, Ownership structure and top executive turnover, Journal of Financial Economics 45 (1997) 193-221.

[26]D.J. Denis, T.A. Kruse, Managerial discipline and corporate restructuring following performance declines, Journal of Financial Economics 55 (2000) 391-424.

[27]E. Dimson, Risk measurement when shares are subject to infrequent trading, Journal of Financial Economics 7 (1979) 197-226.

[28]E.F. Fama, Agency problems and the theory of the firm, Journal of Political Economy 88 (1980) 288-307.

[29] J. Franks, C. Mayer, L. Renneboog, Who disciplines the management of poorly performing companies?, Journal of Financial Intermediation 10 (2001) 209-248. 
[30]FRC, The Combined Code and associated guidance, available online at: http://www.frc.org.uk/CORPORATE/COMBINEDCODE.CFM, 2009.

[31]R. Gibbons, K.J. Murphy, Relative performance evaluation for chief executive officers, Industrial and Labor Relations Review 43 (1990) 30-S-51-S.

[32] R. Gibbons, K.J. Murphy, Optimal incentive contracts in the presence of career concerns: Theory and evidence, Journal of Political Economy 100 (1992) 468-505.

[33] S. Girma, S. Thompson, P. Wright, Merger activity and executive pay, Economica 73 (2006) 321-339.

[34]S. Girma, S. Thompson, P. Wright, Corporate governance reforms and executive compensation determination: Evidence from the UK, Manchester School 75 (2007) 65-81.

[35] W.H. Greene, Econometric Analysis, Prentice Hall, Upper Saddle River, 2000.

[36] S.J. Grossman, O. Hart, An analysis of the principal-agent problem, Econometrica 51 (1983) 7-45.

[37] K.F. Hallock, Reciprocally interlocking boards of directors and executive compensation, Journal of Financial and Quantitative Analysis 32 (1997) 331-344.

[38] J. Heckman, Sample selection bias as a specification error, Econometrica 47 (1979) 153-161.

[39]B. Holmström, Moral hazard and observability, Bell Journal of Economics 10 (1979) 74-91.

[40]B. Holmström, Managerial incentive schemes - a dynamic perspective, in: Essays in Economics and Management in Honour of Lars Wahlbeck, Helsinki, 1982.

[41] M.C. Jensen, W.H. Meckling, Theory of the firm: Managerial behavior, agency costs, and ownership structure, Journal of Financial Economics 3 (1976) 305-360.

[42] M.C. Jensen, K.J. Murphy, Performance pay and top-management incentives, Journal of Political Economy 98 (1990) 225-264.

[43] M.C. Jensen, K.J. Murphy, E.G. Wruck, Where we have been, how we got there, what are the problems and how to fix them, Working paper, Harvard NOM, http://ssrn.com/abstract=561305, 2004.

[44] L. Jin, CEO compensation, diversification, and incentives, Journal of Financial Economics 66 (2002) 2963.

[45] K. John, L.W. Senbet, Corporate governance and board effectiveness, Journal of Banking and Finance 22 (1998) 371-403.

[46] C. Kahn, A. Winton, Ownership structure, speculation, and shareholder intervention, Journal of Finance 53 (1998) 99-129.

[47] O. Kim, Y. Suh, Incentive efficiency of compensation based on accounting and market performance, Journal of Accounting and Economics 16 (1993) 25-53. 
[48] C. Kulich, G. Trojanowski, M.K. Ryan, S.A. Haslam, L. Renneboog, Who gets the carrot and who gets the stick? Evidence of gender disparities in executive remuneration, Strategic Management Journal, 32 (2011) 301-321.

[49] W. Lewellen, C. Loderer, K. Martin, Executive compensation and executive incentive problems: An empirical analysis, Journal of Accounting and Economics 9 (1987) 287-310.

[50] Manifest, Directors' Remuneration Report Disclosure: A Manifest Review, online report, http://www.manifest.co.uk/reports/remuneration/remuneration_report_disclosure.htm, 2003.

[51] Manifest, UK Corporate Governance Milestones, online report, http://www.manifest.co.uk/reports/governance/UK\%20Corporate\%20Governance\%20Milestones.pdf, 2004.

[52] K.J. Martin, J.J. McConnell, Corporate performance, corporate takeovers, and management turnover, Journal of Finance 46 (1991) 671-687.

[53]H. Mehran, Executive compensation structure, ownership, and firm performance, Journal of Financial Economics 38 (1995) 163-184.

[54] W.H. Mikkelson, M.M. Partch, The decline of takeovers and disciplinary managerial turnover, Journal of Financial Economics 44 (1997) 205-228.

[55] K.J. Murphy, Corporate performance and managerial remuneration: An empirical analysis, Journal of Accounting and Economics 7 (1985) 11-42.

[56]K.J. Murphy, Incentives, learning, and compensation: A theoretical and empirical investigation of managerial labor contracts, RAND Journal of Economics 17 (1986) 59-76.

[57] M.P. Narayanan, Form of compensation and managerial decision horizon, Journal of Financial and Quantitative Analysis 31 (1996) 467-491.

[58]E. Ofek, D. Yermack, Taking stock: Equity-based compensation and the evolution of managerial ownership, Journal of Finance 55 (2000) 1367-1384.

[59]R. Parrino, CEO turnover and outside succession: A cross-sectional analysis, Journal of Financial Economics 46 (1997) 165-197.

[60] M. Roe, Political Determinants of Corporate Governance, Oxford University Press, Oxford, 2002.

[61]S. Rosenstein, J.G. Wyatt, Inside directors, board effectiveness, and shareholder wealth, Journal of Financial Economics 44 (1997) 229-250.

[62] J.M. Salas, Entrenchment, governance, and the stock price reaction to sudden executive deaths, Journal of Banking and Finance 34 (2010) 656-666. 
[63] R.G. Sloan, Accounting earnings and top executive compensation, Journal of Accounting and Economics 16 (1993) 55-100.

[64] O. Vasicek, A note on using cross-sectional information in Bayesian estimation of security betas, Journal of Finance 28 (1973) 1233-1239.

[65] M.S. Weisbach, Outside directors and CEO turnover, Journal of Financial Economics 20 (1988) 431-460.

[66]D. Yermack, Flights of fancy: Corporate jets, CEO perquisites, and inferior shareholder returns, Journal of Financial Economics 80 (2006) 211-242.

[67]D. Yermack, High market valuation of companies with a small board of directors, Journal of Financial Economics 40 (1996) 185-211. 
Table 1. Descriptive statistics.

\begin{tabular}{|c|c|c|c|c|c|c|}
\hline & \multicolumn{3}{|c|}{ Pre-reform sample: 1988-1993 } & \multicolumn{3}{|c|}{ Post-reform sample: $1999-2004$} \\
\hline & Median & Mean & Std. dev. & Median & Mean & Std. dev. \\
\hline \multicolumn{7}{|l|}{ CEO turnover } \\
\hline CEO dismissal (\%) & 0.0 & 11.0 & 31.3 & 0.0 & 9.9 & 29.9 \\
\hline \multicolumn{7}{|l|}{ CEO compensation } \\
\hline Ind.-adj. logarithm of cash compensation & 0.0 & 0.0 & 0.6 & 0.0 & 0.0 & 0.8 \\
\hline Logarithm of cash compensation & 11.9 & 11.9 & 0.7 & 12.7 & 12.7 & 0.8 \\
\hline Ind.-adj. logarithm of total compensation & na & na & na & 0.0 & 0.1 & 0.9 \\
\hline Logarithm of total compensation & na & na & na & 12.9 & 13.0 & 1.0 \\
\hline \multicolumn{7}{|l|}{ CEO characteristics } \\
\hline CEO age (years) & 52.0 & 52.6 & 6.3 & 51.0 & 50.5 & 7.5 \\
\hline CEO tenure (years) & 4.0 & 5.2 & 5.3 & 2.9 & 4.9 & 5.4 \\
\hline CEO is the board chairman (\%) & 0.0 & 33.5 & 47.2 & 0.0 & 15.4 & 36.1 \\
\hline \multicolumn{7}{|l|}{ Board composition } \\
\hline Proportion of non-executive directors (\%) & 61.5 & 61.4 & 15.0 & 50.0 & 50.1 & 14.6 \\
\hline Board size & 9.0 & 9.4 & 3.5 & 7.0 & 7.7 & 2.8 \\
\hline Remuneration committee presence (dummy) & 0.0 & 25.9 & 43.8 & 100 & 100 & na \\
\hline \multicolumn{7}{|l|}{ Ownership variables (all in \%) } \\
\hline CEO stake (\%) & 0.0 & 3.0 & 8.1 & 0.0 & 4.5 & 11.7 \\
\hline Executives' stake (\%) & 0.1 & 4.6 & 10.8 & 1.3 & 6.0 & 11.4 \\
\hline Non-executives’ stake (\%) & 0.0 & 3.9 & 9.6 & 0.0 & 3.0 & 8.7 \\
\hline Institutions’ stake (\%) & 13.0 & 16.6 & 16.1 & 22.5 & 24.6 & 17.7 \\
\hline Families/indiv.'s and corporations' stake (\%) & 0.0 & 8.2 & 14.1 & 0.0 & 5.2 & 11.0 \\
\hline \multicolumn{7}{|l|}{ Firm-specific control variables } \\
\hline Logarithm of firm size & 11.3 & 11.3 & 1.8 & 11.9 & 12.0 & 2.3 \\
\hline Capital gearing (\%) & 29.7 & 32.7 & 24.8 & 16.5 & 21.4 & 46.2 \\
\hline Risk (\%) & 34.4 & 37.4 & 13.1 & 30.4 & 33.0 & 13.2 \\
\hline
\end{tabular}


Table 2. Sample selection models explaining CEO turnover and industry-adjusted compensation.

Model 1A: Pre-reform Model 1B: Post-reform $\quad$ Model 1C: Post-reform

Panel A: Selection equations

Intercept
Performance indicators

Industry-adjusted ROA in year $t-1$

Firm size, leverage, and risk

Firm size

Capital gearing

Risk

0.027

$-0.00256$

0.229

0.076

0.211

$-0.00603$

0.286

0.00332

0.00425
Abnormal stock returns in year $t-1$
0.04218

0.00711

$-0.08378$

0.00055

0.00297

Estimate

2.22414

Th

0.00

$\mathrm{p}$-value

0.000

0.477

0.004

0.05188

0.00589

0.371

0.017

\begin{tabular}{cc}
\multicolumn{3}{c}{ and 1 otherwise. } \\
\hline Estimate & $\mathrm{p}$-value \\
\hline 1.94549 & 0.000
\end{tabular}

Year and industry control variables

Year dummies

Industry dummies

\begin{tabular}{ccc} 
Yes & Yes & Yes \\
Yes & Yes & Yes \\
\hline$\chi^{2}(20)=104.29$ & $\chi^{2}(20)=102.41$ & $\chi^{2}(20)=103.62$ \\
$<0.001$ & $<0.001$ & $<0.001$
\end{tabular}

Wald $\chi^{2}$

$<0.001$

0.000

$-0.06409$

0.001

0.792

0.00111

0.600

0.457

0.00472

0.224

P-value for $\chi^{2}$

Panel B: Regression equations

\begin{tabular}{|c|c|c|c|c|c|c|}
\hline \multirow[t]{2}{*}{ Dependent variable: } & \multicolumn{2}{|c|}{$\begin{array}{l}\text { Industry-adjusted CEO } \\
\text { monetary remuneration }\end{array}$} & \multicolumn{2}{|c|}{$\begin{array}{l}\text { Industry-adjusted CEO } \\
\text { monetary remuneration }\end{array}$} & \multicolumn{2}{|c|}{$\begin{array}{c}\text { Industry-adjusted CEO } \\
\text { total remuneration }\end{array}$} \\
\hline & Estimate & p-value & Estimate & p-value & Estimate & p-value \\
\hline Intercept & -3.06839 & 0.000 & -3.02736 & 0.000 & -3.93953 & 0.000 \\
\hline \multicolumn{7}{|l|}{ Performance indicators } \\
\hline Abnormal stock returns in year $t-1$ & 0.00116 & 0.009 & 0.05319 & 0.006 & 0.06694 & 0.015 \\
\hline Industry-adjusted ROA in year $t-1$ & 0.00420 & 0.008 & 0.00296 & 0.015 & 0.00277 & 0.074 \\
\hline \multicolumn{7}{|l|}{ Firm size, leverage, and risk } \\
\hline Firm size & 0.24891 & 0.000 & 0.22409 & 0.000 & 0.28719 & 0.000 \\
\hline Capital gearing & 0.00086 & 0.356 & -0.00205 & 0.075 & -0.00165 & 0.250 \\
\hline Risk & 0.00535 & 0.038 & 0.00966 & 0.000 & 0.01341 & 0.000 \\
\hline \multicolumn{7}{|l|}{ Year control variables } \\
\hline Year dummies & \multicolumn{2}{|c|}{ Yes } & \multicolumn{2}{|c|}{ Yes } & \multicolumn{2}{|c|}{ Yes } \\
\hline Wald $\chi^{2}$ & \multicolumn{2}{|c|}{$\chi^{2}(9)=307.05$} & \multicolumn{2}{|c|}{$\chi^{2}(9)=449.80$} & \multicolumn{2}{|c|}{$\chi^{2}(9)=424.28$} \\
\hline P-value for $\chi^{2}$ & \multicolumn{2}{|c|}{$<0.001$} & \multicolumn{2}{|c|}{$<0.001$} & \multicolumn{2}{|c|}{$<0.001$} \\
\hline \multicolumn{7}{|l|}{ Panel C: Model statistics and tests } \\
\hline Total no. of observations & \multicolumn{2}{|c|}{868} & \multicolumn{2}{|c|}{2282} & \multicolumn{2}{|c|}{2277} \\
\hline No. of censored observations & \multicolumn{2}{|c|}{102} & \multicolumn{2}{|c|}{314} & \multicolumn{2}{|c|}{314} \\
\hline No. of uncensored observations & \multicolumn{2}{|c|}{766} & \multicolumn{2}{|c|}{1968} & \multicolumn{2}{|c|}{1963} \\
\hline Log-likelihood & \multicolumn{2}{|c|}{-658.71} & \multicolumn{2}{|c|}{-2255.21} & \multicolumn{2}{|c|}{-2728.93} \\
\hline $\begin{array}{l}\text { Wald } \chi^{2} \text { statistics for testing } \\
\text { joint significance of two equations }\end{array}$ & \multicolumn{2}{|c|}{$\chi^{2}(29)=676.33$} & \multicolumn{2}{|c|}{$\chi^{2}(29)=822.22$} & \multicolumn{2}{|c|}{$\chi^{2}(29)=780.08$} \\
\hline P-value for $\chi^{2}$ & \multicolumn{2}{|c|}{$<0.001$} & \multicolumn{2}{|c|}{$<0.001$} & & \\
\hline Estimate of $\rho$ & & & & & & \\
\hline $\begin{array}{l}\text { Wald } \chi^{2} \text { statistics for testing } \rho=0 \\
\text { (tests of equations independence) }\end{array}$ & $\chi^{2}(1$ & & $\chi^{2}(1)$ & & $\chi^{2}(1)$ & 7.68 \\
\hline P-value for $\chi^{2}$ & & & & & & \\
\hline
\end{tabular}




\section{Table 3. Sample selection models explaining CEO turnover and industry-adjusted compensation.}

Model 2A: Pre-reform Model 2B: Post-Reform Model 2C: Post-Reform

Panel A: Selection equations

Intercept
Performance indicators

Abnormal stock returns in year $t-1$

Industry-adjusted ROA in year $t-1$

0.00654

0.00907

0.019

0.315

0.68673
0.01338

0.187

0.523

0.60951

0.00695

0.174

0.751

\section{Board composition}

Board size

Stock price perform. * Board size

Accounting perform. * Board size

Proportion of non-executive directors

Stock price perform. * Prop. of non-executives

Accounting perform. * Prop. of non-executives

$\mathrm{CEO}$ is also the chairman

Stock price perf. * CEO is also the chairman

Accounting perf. * $\mathrm{CEO}$ is also the chairman

\section{Ownership concentration}

Executives' stakes

Stock price perform. * Executives' stakes

Accounting perform. * Executives' stakes

Outside block holdings

Stock price perform. * Outside block holdings

Accounting perform. * Outside block holdings

Non-executives' stakes

Stock price perform. * Non-executives' stakes

Accounting perform. * Non-executives' stakes

Firm size, leverage, and risk

Firm size

Capital gearing

Risk

\section{Year and industry control variables}

Year dummies

Industry dummies

Wald $\chi^{2}$

P-value for $\chi^{2}$

$\begin{array}{llllll}-0.95282 & 0.008 & 0.11349 & 0.484 & 0.14205 & 0.358 \\ 0.00395 & 0.517 & -0.25591 & 0.229 & -0.20581 & 0.305 \\ 0.01521 & 0.223 & -0.01108 & 0.282 & -0.00893 & 0.398 \\ -0.01339 & 0.024 & 0.00314 & 0.321 & 0.00435 & 0.173 \\ -0.00008 & 0.574 & -0.00201 & 0.658 & -0.00225 & 0.604 \\ -0.00013 & 0.679 & 0.00028 & 0.194 & 0.00032 & 0.168 \\ 0.30943 & 0.049 & -0.27086 & 0.038 & -0.34720 & 0.005 \\ -0.00278 & 0.632 & 0.01375 & 0.935 & -0.05373 & 0.720 \\ -0.00367 & 0.721 & 0.00835 & 0.325 & 0.01030 & 0.175\end{array}$

$\begin{array}{llllll}0.05166 & 0.178 & 0.00506 & 0.166 & 0.00487 & 0.181 \\ 0.00037 & 0.188 & -0.00038 & 0.952 & -0.00060 & 0.921 \\ -0.00047 & 0.512 & -0.00002 & 0.924 & -0.00004 & 0.864 \\ -0.00476 & 0.283 & -0.00212 & 0.364 & -0.00246 & 0.297 \\ -0.00006 & 0.611 & 0.00187 & 0.665 & -0.00025 & 0.952 \\ 0.00003 & 0.907 & -0.00017 & 0.073 & -0.00016 & 0.095 \\ 0.00375 & 0.614 & -0.00523 & 0.277 & -0.00405 & 0.408 \\ -0.00045 & 0.004 & -0.00533 & 0.533 & -0.00453 & 0.597 \\ -0.00016 & 0.805 & -0.00010 & 0.789 & -0.00034 & 0.444 \\ & & & & & \\ 0.10879 & 0.105 & -0.09294 & 0.001 & -0.07260 & 0.010 \\ 0.00010 & 0.977 & 0.00048 & 0.826 & 0.00015 & 0.940 \\ -0.00633 & 0.416 & 0.00713 & 0.043 & 0.00842 & 0.015\end{array}$

$\begin{array}{llllll}0.05166 & 0.178 & 0.00506 & 0.166 & 0.00487 & 0.181 \\ 0.00037 & 0.188 & -0.00038 & 0.952 & -0.00060 & 0.921 \\ -0.00047 & 0.512 & -0.00002 & 0.924 & -0.00004 & 0.864 \\ -0.00476 & 0.283 & -0.00212 & 0.364 & -0.00246 & 0.297 \\ -0.00006 & 0.611 & 0.00187 & 0.665 & -0.00025 & 0.952 \\ 0.00003 & 0.907 & -0.00017 & 0.073 & -0.00016 & 0.095 \\ 0.00375 & 0.614 & -0.00523 & 0.277 & -0.00405 & 0.408 \\ -0.00045 & 0.004 & -0.00533 & 0.533 & -0.00453 & 0.597 \\ -0.00016 & 0.805 & -0.00010 & 0.789 & -0.00034 & 0.444 \\ & & & & & \\ 0.10879 & 0.105 & -0.09294 & 0.001 & -0.07260 & 0.010 \\ 0.00010 & 0.977 & 0.00048 & 0.826 & 0.00015 & 0.940 \\ -0.00633 & 0.416 & 0.00713 & 0.043 & 0.00842 & 0.015\end{array}$

\begin{tabular}{ccc} 
Yes & Yes & Yes \\
Yes & Yes & Yes \\
\hline$\chi^{2}(38)=153.55$ & $\chi^{2}(38)=156.85$ & $\chi^{2}(38)=143.55$ \\
$<0.001$ & $<0.001$ & $<0.001$
\end{tabular}

Table continues on next page. 
Table 3 - continued.

Panel B: Regression equations

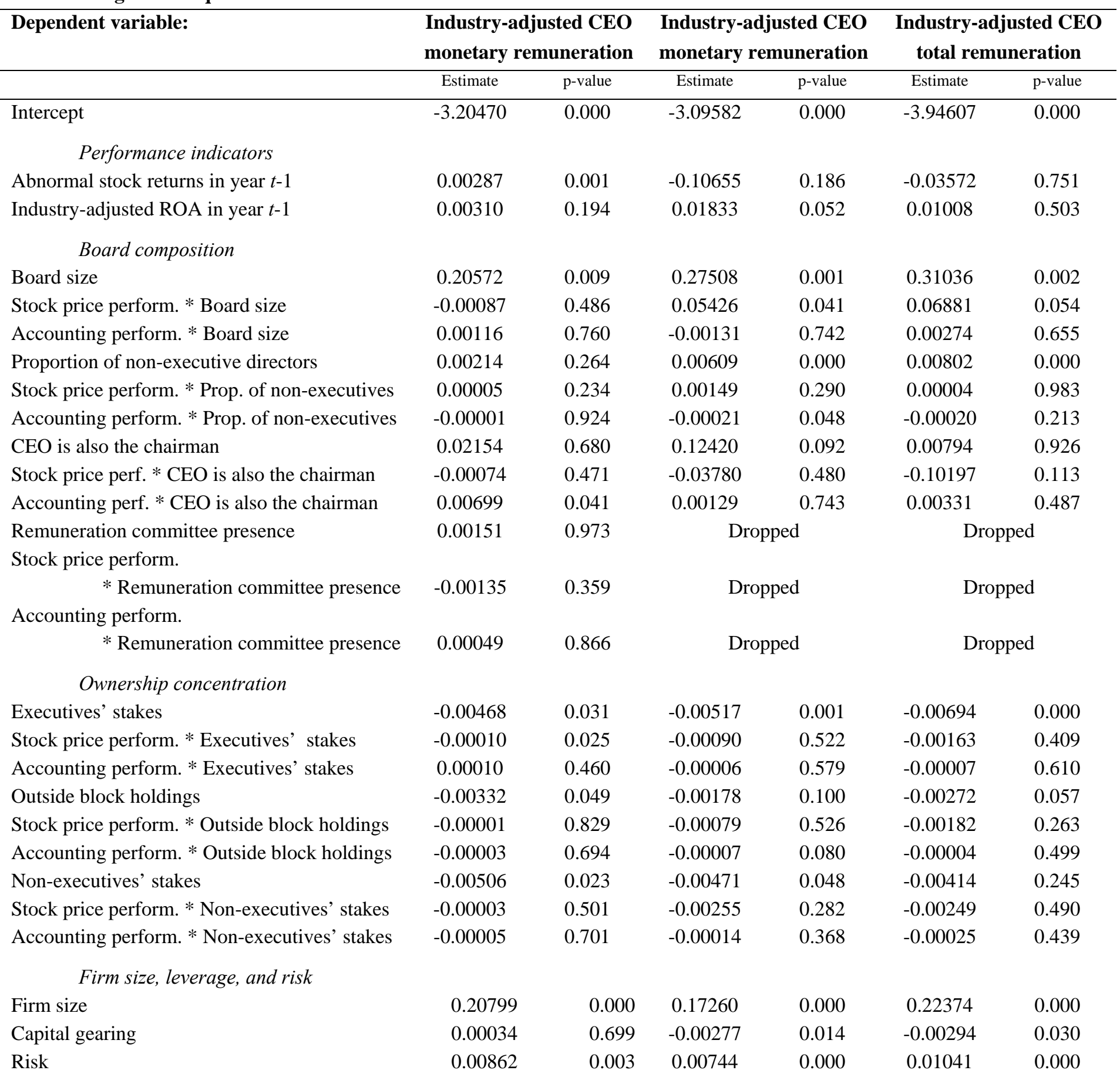

Year control variables

\begin{tabular}{lccc} 
Year dummies & Yes & Yes & Yes \\
\hline Wald $\chi^{2}$ & $\chi^{2}(30)=481.57$ & $\chi^{2}(27)=591.29$ & $\chi^{2}(27)=546.76$ \\
P-value for $\chi^{2}$ & $<0.001$ & $<0.001$ & $<0.001$ \\
\hline
\end{tabular}


Table 3 - continued.

Model 2A: Pre-reform Model 2B: Post-reform $\quad$ Model 2C: Post-reform

Panel C: Model statistics and tests

\begin{tabular}{|c|c|c|c|}
\hline Total no. of observations & 847 & 1909 & 1905 \\
\hline No. of censored observations & 101 & 300 & 300 \\
\hline No. of uncensored observations & 746 & 1609 & 1605 \\
\hline Wald $\chi^{2}$ statistics for testing & & $\chi^{2}(65)=1322.83$ & \\
\hline joint significance of two equations & $\chi^{2}(68)=964.06$ & & $\chi^{2}(65)=1096.07$ \\
\hline P-value for $\chi^{2}$ & $<0.001$ & $<0.001$ & $<0.001$ \\
\hline $\begin{array}{l}\text { Wald } \chi^{2} \text { statistics for testing } \rho=0 \\
\text { (tests of equations independence) }\end{array}$ & $\chi^{2}(1)=1.10$ & $\chi^{2}(1)=185.38$ & $\chi^{2}(1)=166.45$ \\
\hline P-value for $\chi^{2}$ & 0.2953 & $<0.001$ & $<0.001$ \\
\hline
\end{tabular}


Table 4. Fixed-effect panel regressions explaining CEO industry-adjusted compensation for censored sample (CEOs who are not newly appointed).

Model 3A: Pre-reform Model 3B: Post-reform $\quad$ Model 3C: Post-reform

Panel A: Model estimates

Dependent variable:

\begin{tabular}{|c|c|c|c|c|c|c|}
\hline & \multicolumn{2}{|c|}{ monetary remuneration } & \multicolumn{2}{|c|}{ monetary remuneration } & \multicolumn{2}{|c|}{ total remuneration } \\
\hline & Estimate & p-value & Estimate & $\mathrm{p}$-value & Estimate & p-value \\
\hline Intercept & -0.34233 & 0.299 & -3.10998 & 0.000 & -3.54278 & 0.000 \\
\hline \multicolumn{7}{|l|}{ Performance indicators } \\
\hline Abnormal stock returns in year $t-1$ & 0.00094 & 0.001 & 0.02169 & 0.096 & 0.01629 & 0.404 \\
\hline Industry-adjusted ROA in year $t-1$ & -0.00009 & 0.889 & 0.00069 & 0.340 & 0.00025 & 0.816 \\
\hline \multicolumn{7}{|l|}{ Firm size, leverage, and risk } \\
\hline Firm size & 0.04280 & 0.110 & 0.23682 & 0.000 & 0.26992 & 0.000 \\
\hline Capital gearing & -0.00033 & 0.593 & 0.00173 & 0.060 & 0.00438 & 0.002 \\
\hline Risk & -0.00224 & 0.215 & 0.00586 & 0.010 & 0.00642 & 0.059 \\
\hline
\end{tabular}

Other control variables

Year dummies

Yes

Yes

Yes

Panel B: Model statistics and tests

\begin{tabular}{lccc}
\hline$\sigma_{\alpha}$ & 0.536 & 0.476 & 0.573 \\
$\sigma_{e}$ & 0.201 & 0.283 & 0.424 \\
$\rho$ & 0.877 & 0.739 & 0.646 \\
F-test for all $\alpha_{i}=$ & $\mathrm{F}(215,558)=11.93$ & $\mathrm{~F}(723,1310)=6.86$ & $\mathrm{~F}(721,1307)=4.54$ \\
P-value for F & $<0.001$ & $<0.001$ & $<0.001$ \\
Corr $\left(\alpha_{i}, X b\right)$ & 0.457 & -0.079 & $\mathrm{~F}(9,1307)=20.95$ \\
\hline Model F-test & $\mathrm{F}(9,558)=7.96$ & $\mathrm{~F}(9,1310)=38.78$ & 0.001 \\
P-value for F & $<0.001$ & $<0.001$ & 0.126 \\
$\mathrm{R}^{2}$ - within & 0.114 & 0.210 & 0.505 \\
$\mathrm{R}^{2}$ - between & 0.406 & 0.489 & 0.428 \\
$\mathrm{R}^{2}$ - overall & 0.327 & 0.440 & 724 \\
No. of groups & 216 & 2043 & 2038 \\
No. of observations & 783 & & 722 \\
\hline
\end{tabular}


Table 5. Fixed-effect panel regressions explaining CEO industry-adjusted compensation for censored sample (CEOs who are not newly appointed).

Model 4A: Pre-reform Model 4B: Post-reform $\quad$ Model 4C: Post-reform

Panel A: Model estimates

Dependent variable:

\section{Industry-adjusted CEO}

Industry-adjusted CEO Industry-adjusted CEO

monetary remuneration

Estimate $\quad \mathrm{p}$-value

Intercept

Performance indicators

Abnormal stock returns in year $t-1$

Industry-adjusted ROA in year $t-1$

$-0.16453$

0.00043

0.400

0.00152

0.254

-0.09640
0.00711

0.105

0.306

$-0.08536$

0.00249

0.343

0.813

\section{Board composition}

Board size

Stock price performance * Board size

Accounting performance * Board size

Proportion of non-executive directors

Stock price performance

* Proportion of non-executives

Accounting performance

* Proportion of non-executives

CEO is also the chairman

Stock price perf. * CEO is also the chairman

Accounting perf. * CEO is also the chairman

Remuneration committee presence

Stock price performance

* Remuneration committee presence

Accounting performance

* Remuneration committee presence

\section{Ownership concentration}

Executives' stakes

Stock price perform. * Executives' stakes

Accounting perform. * Executives' stakes

Outside block holdings

Stock price perf. * Outside block holdings

Accounting perf. * Outside block holdings

Non-executives' stakes

Stock price perform. * Non-executives' stakes

Accounting perform. * Non-executives' stakes

$\begin{array}{ll}-0.00800 & 0.001 \\ 0.00002 & 0.357 \\ -0.00007 & 0.423 \\ -0.00071 & 0.431 \\ -0.00001 & 0.468 \\ -0.00009 & 0.024 \\ -0.00234 & 0.306 \\ -0.00005 & 0.131 \\ 0.00016 & 0.048\end{array}$

-0.00636
-0.00080
0.00007
-0.00035
-0.00115
0.00001
-0.00303
-0.00247
0.00018

0.013

$-0.00978$

0.011

$-0.00695$

0.915

0.13814

0.078

0.10680

0.369

0.00113

0.194

0.08933

0.000

0.09567

0.002

0.00468

0.158

0.00234

0.111

0.00196

0.641

0.00001

0.608

$-0.00005$

0.314

$-0.00783$

0.805

$-0.00008$

0.204

$-0.00015$

0.09724

0.322

0.11932

$-0.15258$

0.00625

0.018

0.00405

0.174

Dropped

Dropped

Dropped

Dropped

\section{Firm size, leverage, and risk}

Firm size

Capital gearing

Risk

$\begin{array}{llllll}0.01892 & 0.504 & 0.21817 & 0.000 & 0.22582 & 0.000 \\ -0.00008 & 0.897 & 0.00076 & 0.518 & 0.00204 & 0.253 \\ -0.00061 & 0.754 & 0.00452 & 0.073 & 0.00160 & 0.674\end{array}$

Other control variables 
Table 5 - continued.

Model 4A: Pre-reform $\quad$ Model 4B: Post-reform $\quad$ Model 4C: Post-reform

Panel B: Model statistics and tests

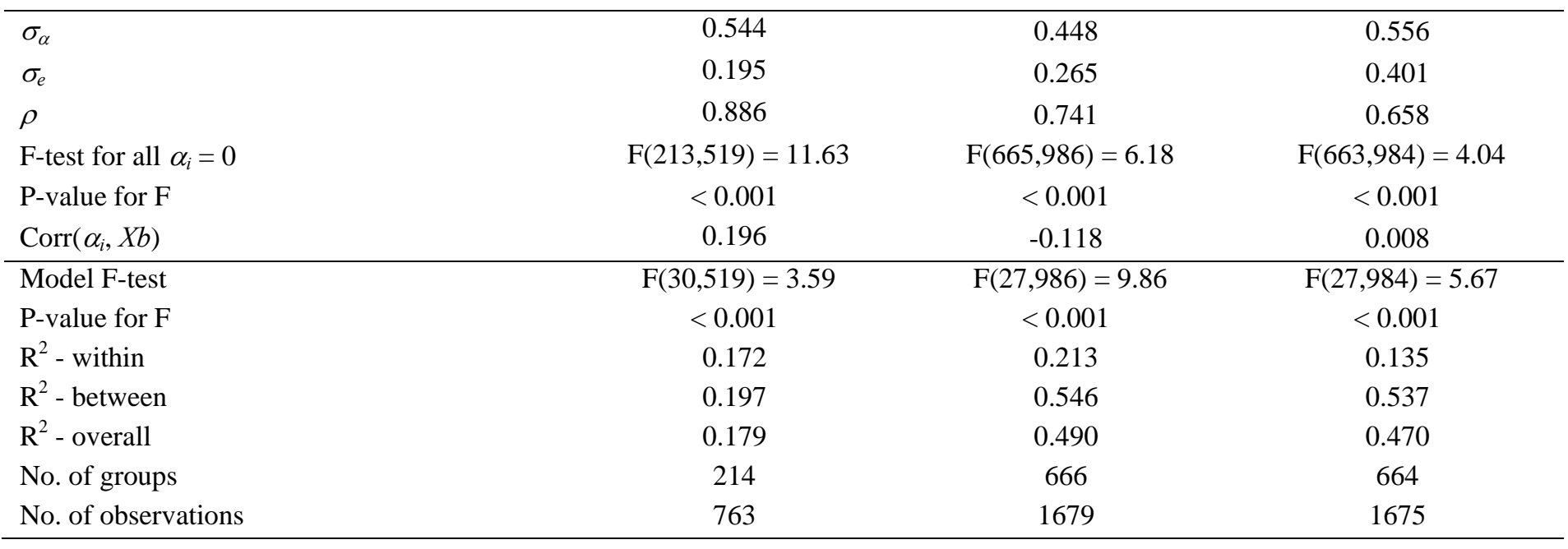

